\title{
Sustainable agriculture: the use of FAMACHA method in Santa Ines sheep in the Semi-arid region of Brazil
}

\section{Agricultura sustentável: uso do método FAMACHA em ovinos Santa Inês no Semiárido do Brasil}

\begin{abstract}
Vinícius Longo Ribeiro Vilela ${ }^{1 *}$; Hermano Manoel Francisco Figueiredo Bezerra ${ }^{2}$; Roberto Alves Bezerra2; Maysa Oliveira Dantas²; Émerson Timóteo Alcântara²; Leonardo Vinícius Silva Oliveira²; Kaio Sá Nóbrega; Fabrício Barcelos Calazans; Thais Ferreira Feitosa ${ }^{1}$; Fabio Ribeiro Braga ${ }^{4}$; Marcelo Beltrão Molento ${ }^{5}$
\end{abstract}

\section{Highlights}

The FAMACHA method allowed an additional productivity of Santa Inês sheep. Haemonchus sp. was the most prevalent parasitic genus (> 94\%) during the entire year. There were up to $97 \%$ of success on the interpretation for the FAMACHA method.

Treatment was predominantly (70\%) during the short rainy season.

\begin{abstract}
Sheep farming is of great importance in generating income to smallholders in semi-arid areas worldwide. Gastrointestinal helminths cause important damage to the animals with poor welfare conditions, impacting in local economies. The objective of this work was to evaluate the FAMACHA method (FMC) in a herd of 60 Santa Inês from Paraíba, Brazil, and to compare the data from previous production years. In order to determine anemic sheep, FMC chart was used in biweekly evaluations for 12 months by trained personnel. Blood and fecal samples were collected monthly to determine packed cell volume (PCV), and parasite fecal egg count (FEC), respectively. The animals were divided into: dry, pregnant and lactating ewes, lambs and rams. Haemonchus was the predominant helminth genus $(94.7 \%)$ during the whole year. There were up to $97 \%$ of success on the interpretation of FMC with 90 to $100 \%$ efficacy in the treatment decision. Among the 1356 evaluations, in only 40 (3\%) were required deworming, being 27 during the rainy season and 13 during

1 Profs. Ph.D., Department of Veterinary Medicine, Instituto Federal da Paraíba, IFPB, Sousa, PB, Brazil. E-mail: vilelavir@ yahoo.com.br; thais.feitosa@ifpb.edu.br

2 Students, Department of Veterinary Medicine, IFPB, Sousa, PB, Brazil. E-mail: hermanomanoel21@gmail.com; roberto. alvesbezerra11@gmail.com; maysaolivera.d@gmail.com; emersontimoteo@gmail.com; leooliver95@gmail.com; kaiovaqueiro35@gmail.com

${ }^{3}$ Student, Postgraduate Program in Animal Science, Universidade Vila Velha, UVV, Vila Velha, ES, Brazil. E-mail: fabriciocalazans@gmail.com

${ }^{4}$ Prof. Ph.D., Postgraduate Program in Animal Science, UVV, Vila Velha, ES, Brazil. E-mail: fabio.braga@uvv.br

5 Prof. Ph.D., Department of Veterinary Medicine, Universidade Federal do Paraná, UFPR, Curitiba, PR, Brazil. E-mail: molento@ufpr.br

* Author for correspondence
\end{abstract}

Received: July 06, 2020 - Approved: Sept. 15, 2020 
the long dry season. A statistically significant correlation $(P<0.01)$ was observed between FEC and PCV for the dry, lactating, and pregnant categories. The data reports a $94 \%$ reduction in deworming, with a greater need for anthelmintic use in lambs and lactating ewes $(P<0.05)$. Our data validates the use of FMC in Santa Inês sheep, which is considered a local resilient breed in the semi-arid region of Brazil. We recommend that animals should be examined during the rainy season to prevent most of the clinical problems.

Key words: Anthelmintic. FEC. Helminths. Hematocrit. Sustainable farming.

\section{Resumo}

A ovinocultura é de extrema importância na geração de renda para pequenos produtores de regiões semiáridas em todo o mundo. Helmintos gastrintestinais causam importantes danos a animais com precárias condições de criação, impactando nas economias locais. O objetivo deste trabalho foi avaliar a utilização do método FAMACHA (FMC) em um rebanho de 60 ovinos da raça Santa Inês no estado da Paraíba, Brasil, e comparar os dados com os de anos produtivos prévios. Para detectar ovinos anêmicos, o cartão FAMACHA foi utilizado quinzenalmente por 12 meses em todos os animais por profissionais treinados. Amostras de sangue e fezes foram coletadas mensalmente para determinar o volume globular (VG) e contagem de ovos por grama de fezes (OPG), respectivamente. Os animais foram divididos em: ovelhas secas, prenhes, lactantes, cordeiros e machos reprodutores. Haemonchus foi o gênero de helminto predominante $(94,7 \%)$ durante todo o ano. Houve mais de $97 \%$ de sucesso na interpretação do FMC com 90 a 100\% de eficácia na decisão de tratamento. Dentre as 1356 avaliações, em apenas 40 (3\%) foi necessário tratamento antihelmíntico, sendo 27 durante o período chuvoso e 13 durante o período seco. Foi observada correlação estatística significativa $(P<0,01)$ entre o OPG e VG para as categorias lactantes, solteiras e prenhas. Os presentes resultados validam o uso do FMC em ovinos Santa Inês, que é considerada uma raça resiliente nativa do semiárido do Brasil. Houve uma maior necessidade de uso anti-helmíntico nas categorias jovens e lactantes $(P<0,05)$. Os dados validaram o uso do FMC, em uma raça resiliente de ovinos no semiárido do Brasil. Recomendamos que os animais sejam examinados durante a estação chuvosa para prevenir a maioria das manifestações clínicas.

Palavras-chave: Agricultura sustentável. Anti-helmíntico. Helmintos. Hematócrito. OPG.

\section{Introduction}

Brazil has a sheep herd of 18.9 million animals, of which 12.6 million (66.7\%) are mainly located in the vast semiarid area of the Northeast region (Instituto Brasileiro de Geografia e Estatística [IBGE], 2018). The majority of animals are on smallholders, providing vital food products (i.e. protein from meat and skin), and serving as a complement to the income of these families. Despite the large animal population, sheep and goats in the semiarid have low level of organization and productivity, reflecting on the low quality of their products (Nóbrega et al., 2005). The semiarid/caatinga is the main biome in the Northeast of Brazil, and animal productivity in native pastures are considerably low, when compared to other northeastern regions such as the Cerrado and the Atlantic forest. While in cultivated pastures the weight gain of lambs can vary from 70 to $180 \mathrm{~g} /$ day, in the Caatinga is less than half of this values. The slaughter condition is reached at later age, and only in the rainy season, with better pasture 
conditions, the weight gain of lambs can be from 40 to $100 \mathrm{~g} /$ day, reaching up to $180 \mathrm{~g} /$ day. This good performance is achieved when animals are also supplemented with a proteinenergy concentrate in the proportion of $1 \%$ of live weight (Albuquerque \& Oliveira, 2015). In general, in the semiarid/caatinga region, an adult sheep or goat needs 1.5 hectare (ha) to produce $20 \mathrm{~kg}$ of animal live weight (Araújo \& Carvalho, 1997), quite different when compared to $50 \%$ of this area in other sheep farming conditions of the country (Poli et al., 2008)

In addition to environmental conditions, such as the long drought, which directly impacts the availability of pasture and water, other factors can also limit animal productivity. Among them, we can mention the parasite infections caused by gastrointestinal helminths (Lima et al., 2010; Torres-Acosta et al., 2012). The most common nematodes of small ruminants in the semi-arid region of Paraíba are Haemonchus sp., Trichostrongylus spp., Strongyloides sp. and Oesophagostomum spp.. Haemonchus contortus frequently comprises about $80 \%$ of the parasite burden of animals in the region (V. D. Vieira et al., 2014). Usually, the animals present mix-infections and clinical signs are characterized by anemia, diarrhea, weight loss, low fertility, drop in milk and meat production and, in cases of massive infections, the animals have high mortality rates (Molento, 2004). Haemonchus contortus has a blood-sucking habit and high biotic capacity and is well adapted to the entire Caatinga, where it is able to survive all year round under harsh weather, surviving mostly in the host as hypobiotic larvae and adults. During the short rainy season Haemonchus sp. and Trichostrongylus spp., can cause high infection rates with increasing fecal egg count (FEC) (W.
W. Silva, Bevilaqua, \& Rodrigues, 2003; Vilela et al., 2013).

$H$. contortus and other nematodes are controlled with the preventive use of commercial anthelmintics at 30 to 90-day interval worldwide, and these recommendations were also adopted to sheep and goats in the semi-arid region during the 70's (L. S. Vieira, Cavalcante, \& Ximenes, 1997), and have been used since. Using this protocol, the animals would be treated four times a year, three during the dry period (from June to February) and one during the short rainy period (from March to May). Even though the frequency of anthelmintic treatments were not as high as seen in other regions, this regime imposes a strong selection pressure for parasite resistance, due to the low parasite population reposition during the dry period. This was demonstrated by Silva, Bezerra, Feitosa and Vilela (2018), where they reported a reduction in albendazole, ivermectin, closantel, levamisole and monepantel efficacy in 20 sheep herds that were evaluated in the semiarid region of Paraíba.

The FAMACHA (FMC) method was developed as an auxiliary strategy for the control of $\mathrm{H}$. contortus with the objective of identifying susceptible (anemic) animals in the herd, reducing the use of anthelmintics (Molento et al., 2011; Vilela et al., 2012). This technique is based on the individual observation of the color of the animals' ocular conjunctiva and the subsequent attribution of a degree (1 to 5 ), which classifies whether an animal is healthy (1) or clinically anemic (5) (Van Wyk and Bath, 2002). In this way, only animals that show signs of anemia $(3,4$ and 5$)$ should be treated. The FMC method has the advantages of reducing the use of anthelmintics, the 
selection pressure for resistance, the cost of medication and also the chemical residues in meat, milk and the environment. The FMC method has been validated in Brazil and is being used in all animal categories (M. B. Molento, Gavião, Depner, \& Pires, 2009), however its use in animals in the semiarid region still needs further studies, especially for categories of animals considered more vulnerable to parasite challenge. The objective of this work was to evaluate the use of FMC in Santa Inês breed raised in a semi-extensive regime in the semiarid region of Brazil.

\section{Material and Methods}

The study was approved by the Animal Care and Ethics Committee of the Federal Institute of Paraíba, IFPB in the municipality of Sousa, state of Paraíba, Brazil (number: 23000,001538,2016/03).

\section{Farm, climate and geographical area}

The present research was carried out at the Sheep Production Sector of the IFPB, located at latitude $-6.8314 \mathrm{~W}$ and longitude -38.3163S. The region has a semi-arid climate with a rainy season from February to May (average of $140 \mathrm{~mm} / \mathrm{month}$ ), where more than $90 \%$ of the rainfall occurs and a long period of drought (average of $15 \mathrm{~mm} / \mathrm{month}$ ). The average annual temperature is $30.6^{\circ} \mathrm{C}$, with a minimum of $28.7^{\circ} \mathrm{C}$ and a maximum of $32.5^{\circ}$ C (Instituto Nacional de Meteorologia [INMET], 2010). The climate data was assessed from the Climate Data Source, which is a location data by the OpenStreetMap.org Project. This is an open data source under the Creative Commons Attribution Share Alike 2.0 (Oedheim, Germany).

\section{Experimental area and animal management}

Between March 2016 and February 2017, a herd of Santa Inês sheep consisted of an average of 60 animals above 3 months of age of both sexes was examined. The animals presented individual records and were identified with health and reproduction information. The herd was subjected to a semiintensive rearing system, grazing in an area of 4 ha of native caatinga vegetation, composed by Mata-pasto (Senna obtusifolia L.), Jurema-preta (Mimosa tenuiflora), Catingueira (Caesalpinia pyramidalis), Marmeleiro (Croton sonderianus), Malva (Malva sp.), Juazeiro (Zizyphus joazeiro), Sabiá (Mimosa caesalpiniifolia), and Favela (Cnidoscolus phyllacanthus), during the day. The animals received a daily supplement with a protein-energy concentrate of corn and soybeans $(0.5 \%$ live weight) late afternoon. The animals received mineral salt and water ad libitum. The routine of antiparasitic treatments prior to this research was of mass treatment at monthly interval. There was a constant rotation of active ingredients, without obeying a technical criterion for choosing the following medication. According to the historical data of the herd in the last five years, the animals were treated 3815 (763 doses/year) times with an average of 12.7 times/animal/year. Before starting the study, the annual mortality rate due to parasites was $27 \%$ (Table 1 ). The highest rate of animal loss occurred during the rainy season (72\%). 
Table 1

Deaths caused by gastrointestinal helminths in a Santa Inês sheep herd from 2011 to 2015 (prior to the study), in the semi-arid Paraíba, Brazil.

\begin{tabular}{|ccccccc|}
\hline & \multicolumn{7}{c}{ Period of evaluation } \\
\cline { 2 - 7 } Month & 2011 & 2012 & 2013 & 2014 & 2015 & Total \\
\hline Jan & 0 & 1 & 0 & 2 & 1 & 4 \\
\hline Feb & 1 & 1 & 0 & 1 & 0 & 3 \\
\hline Mar & 0 & 3 & 2 & 1 & 0 & 6 \\
\hline Apr & 12 & 3 & 6 & 1 & 1 & 18 \\
\hline May & 4 & 2 & 7 & 6 & 4 & 23 \\
\hline Jun & 1 & 0 & 2 & 4 & 3 & 10 \\
\hline Jul & 0 & 1 & 0 & 3 & 0 & 4 \\
\hline Aug & 2 & 1 & 0 & 0 & 0 & 3 \\
\hline Sep & 0 & 0 & 0 & 0 & 0 & 0 \\
\hline Oct & 0 & 1 & 0 & 0 & 0 & 1 \\
\hline Nov & 1 & 0 & 0 & 0 & 2 & 3 \\
\hline Dec & 0 & 0 & 0 & 0 & 0 & 0 \\
\hline Total/year & 21 & 13 & 17 & 18 & 11 & 75 \\
\hline
\end{tabular}

\section{Experimental design}

Initially, four anthelmintics were tested through the fecal egg count reduction test (FECRT), according to Coles et al. (1992). For this, forty animals with FEC above 300 were chosen at random and were divided into four groups ( $n=10)$, receiving: ivermectin $0.8 \%$ (Ivomec, Merial Saúde Animal), albendazole 10\% (Ibazole, Ibasa Saúde Animal), closantel 10\% (Diantel, Hipra Saúde Animal) and levamisole 5\% (Ripercol L, Fort Dodge Saúde Animal). The drugs were administered orally, in a single dose, according to the manufacturer's instructions. The animals were treated on day zero, with fecal collection after 7 and 14 days post-treatment.

FMC was performed in all animals every 2 weeks for 12 months with individual inspection of the ocular conjunctiva. Only animals that presented FMC 3, 4 or 5, were treated immediately. All inspections were taken by the same observer, under natural light, on animals at rest, following the recommendations proposed by van Wyk and Bath (2002). The herd was divided into five categories: pregnant, classified after ultrasound examination; dry, neither pregnant or lactating; lactating with lambs; lambs of both sexes; and rams. Lambs of less than three months of age were not evaluated by FMC.

Individual feces and blood were collected monthly from all animals. FEC was performed according to Gordon and Whitlock (1939). Fecal cultures were performed according to Roberts and O'Sullivan (1950). Red blood cells were used to determine the packed cell volume (PCV) technique according to Ferreira, Viana and Magalhães (1981).

The frequency of the correct interpretations of FMC was verified by 
comparing the results obtained from the PCV of each animal, following the references: FMC 1 (F1): VG $\geq 28 \%, F 2: 23-27 \%, F 3: 18-22 \%, F 4:$ 13-17\%, and F5: $\leq 12$ (van Wyk \& Bath, 2002). The accurate decision to use the medication was based on animals that were correctly identified at FMC 1 and 2, which did not receive anthelmintics, FMC 3 , which received treatment when the body condition score was below 2.5 and FMC 4 and 5 that were treated.

\section{Statistical analysis}

The normality of the data was verified by the Shapiro Wilk test. For the comparison between the groups that had a normal distribution, ANOVA with Tukey's post hoc was used. Non-normal distribution data were analyzed using the Krukal-Wallis test with Dunn's post hoc. In addition, it was verified whether there was a possible linear correlation between the variables VG and FEC for the different groups. The Spearmann coefficient of correlation $\left(\hat{\rho}_{s}\right)$ was determine using the data from the mortality in previous years and climate; mortality and FMC treatments; and FMC treatments and climate data using Excel (Microsoft, Madison, USA). The analyzes were performed with the SPSS 23 program at a $5 \%$ significance level. Descriptive analysis of production data in the pre-FMC years and the FMC year of production was performed.

\section{Results}

Haemonchus sp. was the most prevalent helminth genus (93.3\%) from the coprocultures throughout the evaluated period, followed by Trichostrongylus spp. (5.3\%) and Oesophagostomum sp. (1.4\%) (Table 2). The average monthly FEC values were stratified into five categories, as shown in Figure 1. There was no great variation in the average by category $(P \geq 0.05)$ throughout the year, except for lambs, which had high counts in the months of April, May (rainy season) and September ( $P$ $<0.05)$. Lambs presented the highest annual FEC average (1885), which was significantly different $(P<0.05)$ from the other categories. The FECRT demonstrated an efficacy of 0 , 31,76 and $100 \%$ for ivermectin, albendazole, closantel, and levamisole, respectively. Thus, levamisole was used throughout the evaluation year. A new FECRT was carried out at the end of the experiment showing an efficacy of 34, 0, 71 and 96\% for ivermectin, albendazole, closantel, and levamisole, respectively. The second efficacy data demonstrated the maintenance of the susceptibility of the parasites to levamisole, and somewhat similar results to the other compounds.

\section{Table 2}

Helminth genera (\%) observed in coprocultures of Santa Inês sheep, in the semi-arid region of Paraíba, Brazil

\begin{tabular}{|ccccccccccccc|}
\hline Genus & Mar & Apr & May & Jun & Jul & Aug & Sep & Oct & Nov & Dec & Jan & Feb \\
\hline Haem. & 86 & 96 & 93 & 92 & 96 & 95 & 94 & 99 & 92 & 95 & 91 & 89 \\
\hline Trich. & 14 & 2 & 5 & 6 & 3 & 3 & 5 & - & 8 & 4 & 7 & 8 \\
Oesop. & - & 2 & 2 & 2 & 1 & 2 & 1 & 1 & - & 1 & 2 & 3
\end{tabular}

Haem: Haemonchus sp.; Trich: Trichostrongylus spp.; Oesop: Oesophagostomum sp. 


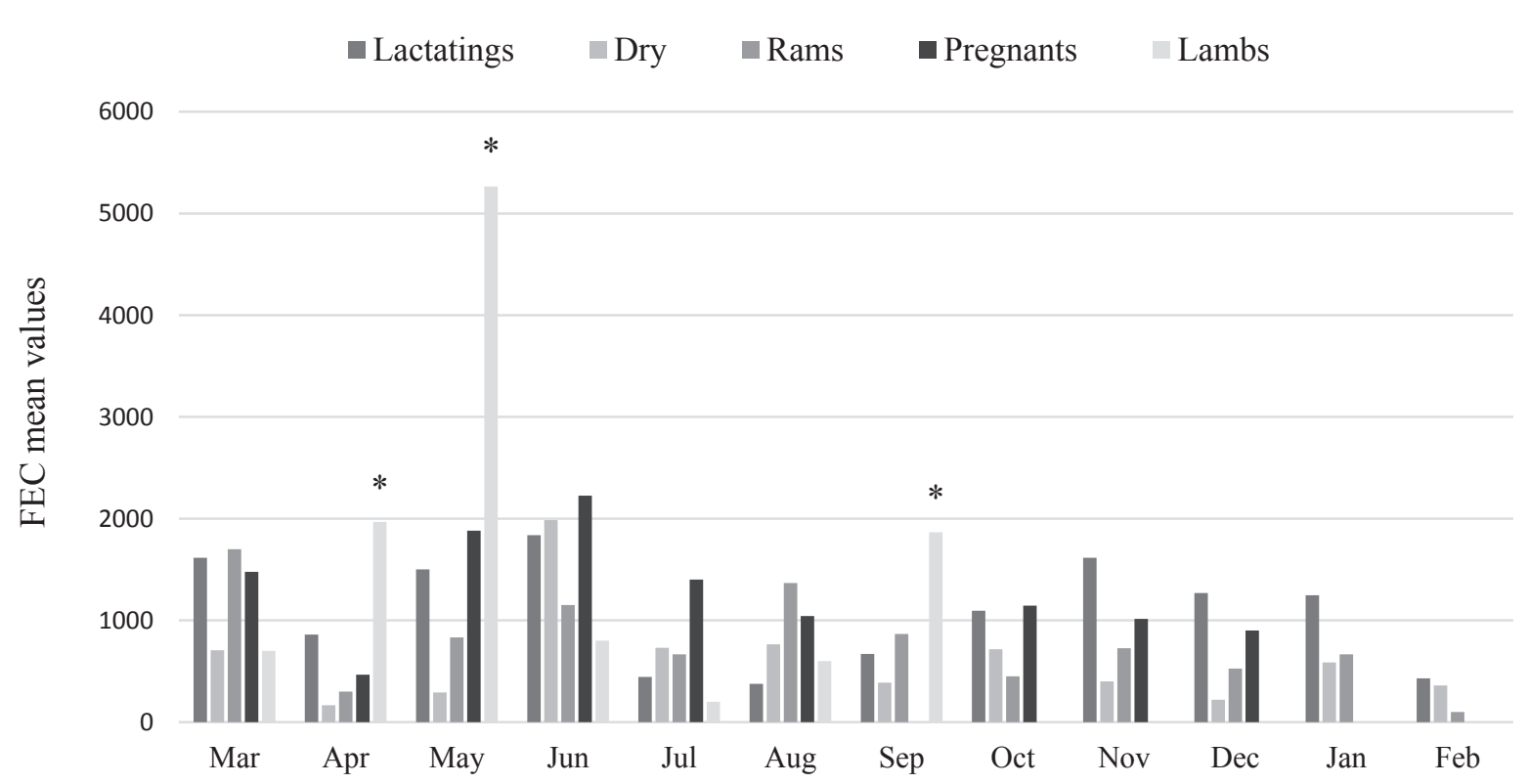

Evaluated months

Figure 1. Monthly fecal egg count (FEC) values according to the animal category in the Semi-arid region of Paraíba, Brazil. * Indicates statistically significant differences according to the Tukey test at $5 \%$.

The PCV did not show any significant variations in the monthly percentage between categories, although in the months of October, November and December 2016 and January 2017, they presented a downward line of PCV. These was possibly due to the long period of drought and poor nutritional value of pastures (data not shown). There was a significant statistical correlation $(P<0.01)$ between FEC and PCV for the lactating $\left(\hat{\rho}_{s}=-0.303\right)$, dry $\left(\hat{\rho}_{s}=\right.$ -0.313) and pregnant $\left(\hat{\rho}_{s}=-0,403\right)$ categories and not for lambs and rams.

Even after a specific FMC training, it was observed that in the first two months, the percentage of correctanswers, when correlating FMC and PCV were low (31 and 68\%). However, after the third month of assessments, these values increased, reaching $97 \%$ in February 2017. The percentage of correct answers in the treatment of anemic animals was much higher (between 90 and 100\%), throughout the evaluation period (Figure 2). We carried out 1356 FMC evaluations, and only 40 (3\%) animals received at least one treatment. Most of the treatments $(n=27,69.8 \%)$ were made during the rainy season and only $13(30.2 \%)$ were during the long dry season (Table 3). Only three animals received two treatments, which indicates a low level of repeat deworming in the herd. There were no deaths of animals due to parasite infection during the evaluated period. When comparing with the pre-FMC years, we observed less use of levamisole after the adoption of FMC. In assessing the distribution of treatments to each animal category, the lactating animals received statistically $(P<0.05)$ more treatments $(24 / 40)$ than the others. Proportionally, considering the amount of treatments per total evaluations in a category, lambs received the most anthelmintic treatments (14.2\%; $\mathrm{P}<0.05$ ) (Table 4). 


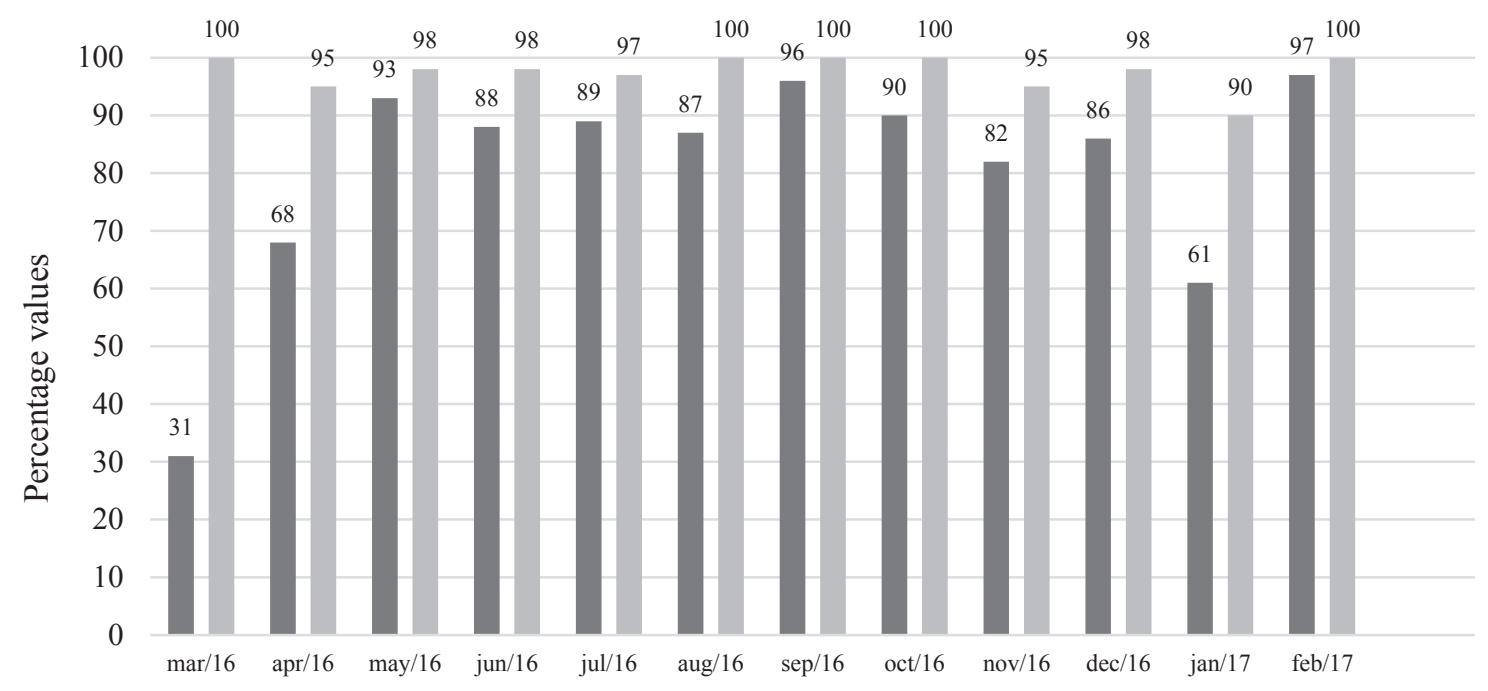

Evaluated months

Figure 2. Monthly percentage of success on the interpretation of the Famacha method (black column) and success on the therapeutic procedures (gray column) in Santa Inês sheep in the semi-arid region of Paraíba, Brazil.

\section{Table 3}

Total Famacha evaluations (FMC) carried out biweekly, type of predominant climate, total amount of treatments and percentage (\%) of monthly treatments of Santa Inês sheep in the semiarid region of Paraíba, Brazil

\begin{tabular}{|ccccc|}
\hline Month $(2 \mathrm{x})$ & Climate & FMC evaluations & Treatments & \% Treated \\
\hline Mar/16 & Rain & 100 & 10 & 10 \\
\hline Apr/16 & Rain & 102 & 5 & 5 \\
\hline May/16 & Rain & 92 & 5 & 5.5 \\
\hline Jun/16 & Dry & 150 & 6 & 4 \\
\hline Jul/16 & Dry & 126 & 2 & 1.5 \\
\hline Aug/16 & Dry & 116 & 0 & 0 \\
\hline Sep/16 & Dry & 112 & 0 & 0 \\
\hline Oct/16 & Dry & 110 & 1 & 1 \\
\hline Nov/16 & Dry & 112 & 2 & 2 \\
\hline Dec/16 & Dry & 112 & 2 & 2 \\
\hline Jan/17 & Rain & 102 & 7 & 7 \\
\hline Feb/17 & Rain & 118 & 0 & 0 \\
\hline Total & --- & 1356 & 40 & 3 \\
\hline
\end{tabular}


Table 4

Values referring to the Famacha degree (1 to 5), total number of evaluations, total number of treatments, and percentage of treatments (\%) by animal category, collected at biweekly interval in sheep in the semiarid region of Paraíba, Brazil

\begin{tabular}{|ccccccccc|}
\hline Categories & 1 & 2 & $3^{*}$ & 4 & 5 & Total & Treatments & Percentage \\
\hline Lactating & 344 & 144 & 36 & 2 & - & 526 & $24^{\mathrm{a}}$ & $4.5^{\mathrm{b}}$ \\
\hline Dry & 308 & 60 & 6 & - & - & 374 & $3^{\mathrm{b}}$ & $0.8^{\mathrm{b}}$ \\
\hline Rams & 72 & 6 & 2 & - & - & 80 & $1^{\mathrm{b}}$ & $1.25^{\mathrm{b}}$ \\
\hline Pregnant & 268 & 54 & 8 & - & - & 330 & $5^{\mathrm{b}}$ & $0.9^{\mathrm{b}}$ \\
\hline Lambs & 18 & 6 & 8 & - & 10 & 42 & $7^{\mathrm{b}}$ & $14.2^{\mathrm{a}}$ \\
\hline Total & 1010 & 270 & 60 & 2 & 10 & 1352 & 40 & 2.7 \\
\hline
\end{tabular}

* Animals assessed with degree 3 may not require antiparasitic treatment. Values followed by different letters in the same column differ statistically by the Tukey's test at $5 \%$.

We have compared the percentage of treatments based on the FMC evaluations, animal mortality from previousyears, and rainfall index during the experiment (Figure 3). It was observed a very high correlation $\left(\rho_{s}=0.913\right)$, between rainfall and the average mortality in the five years prior to the use of FMC. It was also observed a medium correlation between rainfall and the percentage of treatments/ FMC $\left(\rho_{s}=0.602\right)$, and between mortality and percentage of treatments/FMC $\left(\rho_{s}=0.503\right)$.

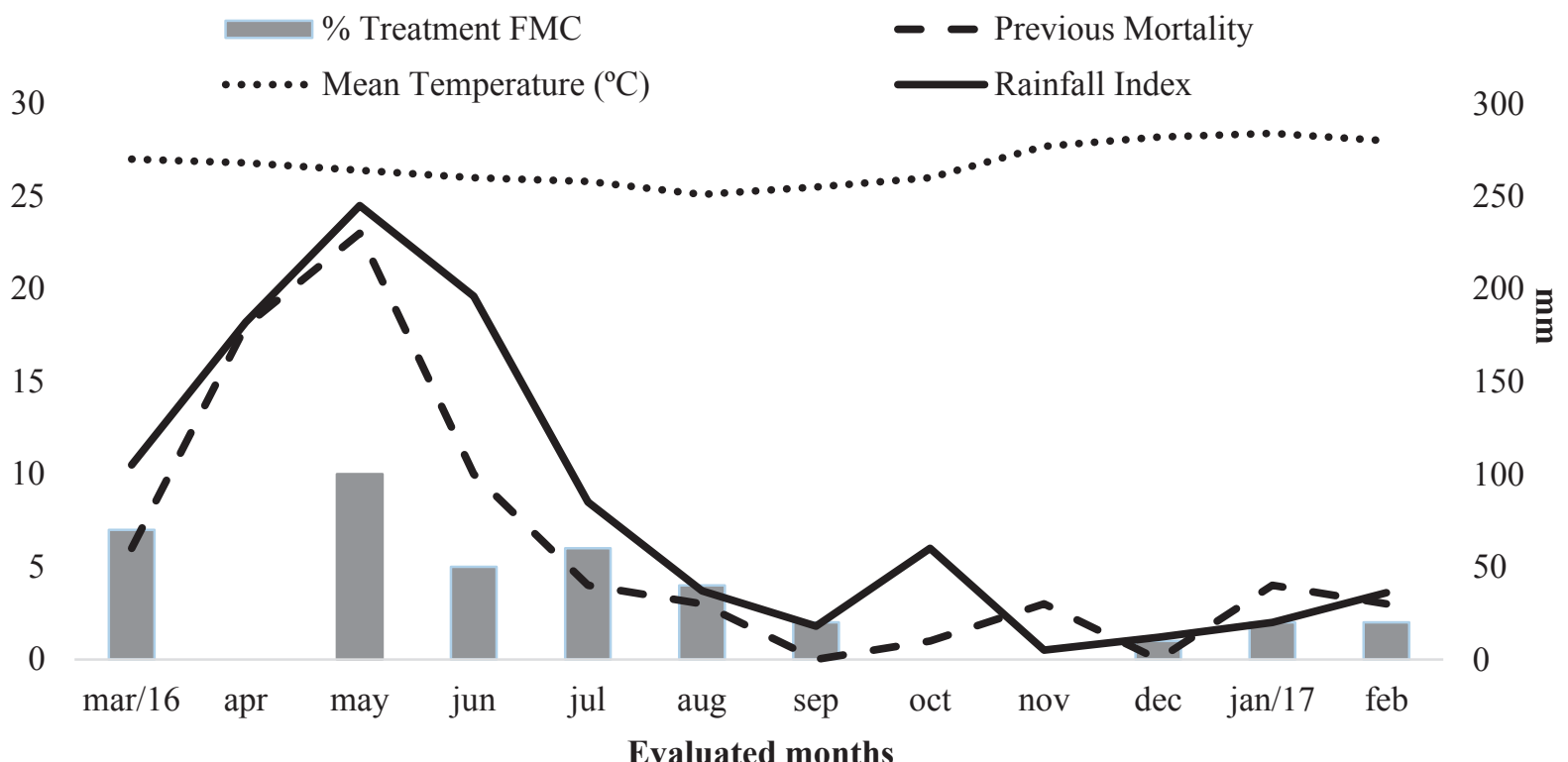

Figure 3. Percentage of FMC treatment, previous mortality, mean temperature and rainfall index at the Sheep Farming Sector of the IFPB, semiarid of Paraíba State, Brazil. 


\section{Discussion}

The identification of helminth genera revealed the considerable prevalence of Haemonchus sp. throughout the year, even though the highest FEC were only during the rainy period. This fact is common throughout the semi-arid region and demonstrates the need for a greater animal health attention during the rainy period. This is especially true when considering the clinical impact of Haemonchus sp. infections and the high presence of freeliving stages, leading to a high infection season (high parasite translation). Other research also reported the predominance of Haemonchus $\mathrm{sp}$. in small ruminants in the semi-arid region (Lima et al., 2010; Melo, Vilela, Feitosa, Almeida, \& Morais, 2013; Vieira et al., 2014). This parasite directly influences the correct FMC interpretation, which must be of at least $60 \%$ prevalence to validate the effectiveness of the method to different categories (Fernandes et al., 2015).

The low success rates of the FMC interpretation at the beginning of the experiment were correlated with the inexperience of the evaluator(s). From the third month of observation on the average number of correct answers increased to 93\% and above. Even in months that presented low rates of correct answers, there were no influences on the efficiency of how to conduct the treatments to the animals. The correctness of the conduct to use FMC reached $100 \%$, remaining above $90 \%$ throughout the evaluation period. Similar data were also obtained by Vilela et al. (2012), when evaluating goat herds in the semi-arid region of Brazil, where the percentage of correct answers in the interpretation of the FMC varied from $32.6 \%$ in the first month to $70 \%$ after the fourth month, proving the importance of proper training. These high rates are related to the method's ability to differentiate resilient individuals from those that are more susceptible, when Haemonchus sp. is predominant (Kaplan et al., 2004; Molento et al., 2004; Riley \& van Wyk, 2009). D. Maia, Rosalinski-Moraes, Van Wyk, Weber and Sotomaior (2014), evidenced that in practical FMC courses in Paraná, Brazil, where a total of 1004 participants performed 20080 classifications, an inversely proportional relationship between the number of animals and the amount of errors in the interpretation of the method $(P<0.05)$.

In January 2017, there was a reduction in the hit rate, probably related to the scarcity of food by the end of the dry period and the beginning of the breeding season, which suddenly decreased the PCV percentage. Although a low PCV may cause difficulty in the interpretation of FMC, it can still maintain the treatment conduct at satisfactory levels, as reported by Molento etal. (2009). The nutritional factor is determinant in gastrointestinal helminth infections, since animals submitted to low nutritional levels can become more susceptible to parasitism, as they are unable to develop an effective immune response (Hoste \& Torres-Acosta, 2011).

The use of FMC provided a $94 \%$ reduction (40/763) in the administration of anthelmintics, when compared to previous years, which had an average of 763 doses/year (V. Vilela, personal information). The present data revealed that in the months of August and September 2016 (dry season), and February 2017 (rains), no animals were treated. In our study, the animals from the Santa Inês breed demonstrated a strong resilience in the face of the Haemonchus sp. challenge since their early age. Similarly, in a comparative study 
with some other European breeds, Santa Inês showed greater resistance to infection caused by gastrointestinal nematodes with lower parasite loads and the need for less anthelmintic treatments (A. F. T. Amarante, Bricarello, Rocha, \& Gennari, 2004; Bricarello et al., 2005). In a study by Amarante et al. (2009), in which the degree of resistance to infections by gastrointestinal nematodes in purebred Santa Inês sheep and crosses of the Santa Inês breed with Dorper, Île de France, Suffolk and Texel was comparatively evaluated, the authors observed that Santa Inês sheep showed greater resistance, presenting the lowest FEC of all breeds.

The data from the 5-year pre-FMC period were used to compare the overall cost and the volume of drugs used. As a comparison, the $1000 \mathrm{ml}$ bottle of Ripercol'L costs $R \$ 90.00$ with a cost per dose of $R \$ 0.36$ ( $4 \mathrm{ml})$. Thus, the 40 doses of levamisole ( $\mathrm{R} \$$ 14.40) used in this experiment, means a saving of $94.5 \%$, when compared to the drug cost of the previous years ( $R \$ 274.70 /$ year). In a study carried out with dairy goats from the semi-arid region of Paraíba, Vilela et al. (2012) obtained a reduction of $79.2 \%$ in the use of anthelmintics after implementing the FMC method. This factor is one of the most important criteria looked by farmers, especially in resource poor areas - emphasizing the need for more sustainable protocols for sheep farming in the semiarid regions of the world.

Lambs and lactating ewes obtained the highest FEC and treatment percentages. In the present study, the high FEC led to a decrease in the PCV of the lambs, dry and pregnant categories, increasing the FMC degree and, consequently, the number of treatments. The rams were released with the ewes all year long and the lambs were born between March and
September of eachyear, withouta fixed breeding schedule, making health control more difficult. This strategy is justified as young animals have a greater number of exposure to parasites and a lower immunological maturity. Ewes, in late gestation and during lactation, have hormonal changes associated with nutritional needs, such as high requirement for metabolizable protein, however, their consumption is generally insufficient to meet the demand during this period (Coop \& Kyriazakis, 1999). The hormonal changes also reflect in immunomodulation, which can decrease the balance of the immune system directly affecting the efficiency of their physiological functions and the ability to fight parasite infections (Costa, Simões, \& RietCorrea, 2011). To reduce these problems, one of the alternatives is to carry out a breeding program that could improve the herd's management, enabling the lambing during the most favorable seasons. We recommend that lambing be centered during the early rainy period, so the ewes would enjoy a better nutritional level. Although the risk for parasite infection is higher than in the other months, the animals would be better prepared and closely followed by FMC. We believe that this strategy would directly increase revenue, as reported by Nogueira et al. (2011). These authors also indicated that ewes can deliver 1.5 times per year during July/August, March-April, or November/December.

Looking at the epidemiology of parasitic infections in the semiarid, and the hostparasite relationship, we determined that the rainy season was responsible for the increase of animal infection (70\% of treatments), clinical signs and death (data from previous years), and that Haemonchus sp. can be controlled with individual bi-weekly examinations. In the five-year period prior to the use of FMC at the 
IFPB, the environmental conditions were highly correlated with animal mortality. Still analyzing the five previous years, and despite numerous deworming, the choice of anthelmintics was incorrect, and should have been based after the FECRT.

During the actual experimental period, we noted that the FMC method was able to identify the animals that needed deworming and, by using an effective drug, the death rate was reduce to zero in the evaluated herd. Therefore, the combination strategy of conducting the FMC observation at biweekly intervals and the use of an effective drug, sheep farming could reach optimal performance, especially during the rainy season. Molento (2004), reported that the use of more than one strategy is advised as sustainable health programs should be based on the integrated system for parasite control, SICOPA (Sistema Integrado de Controle Parasitário). FMC could be used once a month during the dry period but this recommendation needs further analysis in the semiarid conditions. We reinforce that for the success of the FMC method and the reduction of death risk, the correct anthelmintic choice has to be based after the FECRT.

The results of the second FECRT corroborated with the applicability of FMC in maintaining satisfactory drug efficacy rates, allowing the persistence of a refugia population to levamisole. Chagas et al. (2016), also reported a low number of treatments and the consequent low selection pressure of levamisole. The authors used levamisole when applying FMC, at least once a month, for five years. In Uganda, the use of FMC in goats, limited the selection pressure, resulting in the late development of anthelmintic resistance (I. Nabukenya, Akiiki, Olila, Muhangi, \& Höglund, 2014). In the semiarid region of the IFPB, the high number of untreated animals (>90\%) seen in our study had eliminated an impressive number of eggs from susceptible and unexposed adult parasites, amplifying the refugia to levamisole. This strategy still allowed the presence of healthy animals with no clinical implications, reaching a sustainable agriculture production. Due to its large sheep population, integrated control of gastrointestinal helminths in sheep is essential in the semiarid region of Brazil and in similar areas of South America and Africa.

\section{Conclusion}

The use of FMC and monitoring the performance data significantly reduced the need for treatments in animals of various categories, including lactating ewes, allowing sustainable farming in the semiarid region of Brazil. There were up to $97 \%$ success for the FMC interpretation. Haemonchus sp. was the most prevalent parasite genus, and although a peak in FEC from lambs was observed, FEC and PCV showed little variation in the animals. FMC improved farming with Santa Inês, especially during the parasite season.

\section{References}

Albuquerque, F. H. M. A. R., \& Oliveira, L. S. (2015). Produção de ovinos de corte: terminação de cordeiros no Semiárido. Brasília: EMBRAPA.

Amarante, A. F. T., Bricarello, P. A., Rocha, R. A., \& Gennari, S. M. (2004). Resistance of Santa Ines, Suffolk and lle de France lambs to naturally acquired gastrointestinal nematode infections. Veterinary Parasitology, 120(1-2), 91-106. doi: 10.1016/j.vetpar.2003.12.004 
Amarante, A. F. T., Susin, I., Rocha, R. A., Silva, M. B., Mendes, C. Q., \& Pires, A. V. (2009). Resistance of Santa Ines and crossbred ewes to naturally acquired gastrointestinal nematode infections. Veterinary Parasitology, 165(3-4), 273-280. doi: 10.10 16/j.vetpar.2009.07.009

Araújo, J. A., Fo., \& Carvalho, F. C. (1997). Desenvolvimento sustentável da caatinga. Sobral: EMBRAPA Caprinos.

Bricarello, P. A., Amarante, A. F. T., Rocha, R. A., Cabral, S. L., Fo., Huntley, J. F., Houdijk, J. G. M.,... Gennari, S. M. (2005). Influence of dietary protein supply on resistance to experimental infections with Haemonchus contortus in Ile de France and Santa Ines lambs. Veterinary Parasitology, 134(1-2), 99-109. doi: 10.1016/j.vetpar.2005.05.068

Chagas, A. C. S., Domingues, L. F., Gaínza, Y. A., Barioni, W., Jr., Esteves, S. N., \& Niciura, S. C. M. (2016). Target selected treatment with levamisole to control the development of anthelmintic resistance in a sheep flock. Parasitology Research, 115, 1131-1139. doi: 10.1007/s00436-015-4844-x

Coles, G. C., Bauer, C., Borgsteede, F. H., Geerts, S., Klei, T. R., Taylor, M. A., \& Waller, P. J. (1992). World association for the advancement of veterinary parasitology methods for the detection of anthelmintic resistance in nematodes of veterinary importance. Veterinary Parasitology, 44(12), 35-44. doi: 10.1016/0304-4017(92)90 $141-u$

Coop, R. L., \& Kyriazakis, I. (1999). Nutritionparasite interaction. Vetetrinary Parasitology, 84(3-4), 187-204. doi: 10.10 16/S0304-4017(99)00070-9
Costa, V. M. M., Simões, S. V. D., \& Riet-Correa, F. (2011). Controle das parasitoses gastrintestinais em ovinos e caprinos na região semiárida do Nordeste do Brasil. Pesquisa Veterinária Brasileira, 31(1), 65-71. doi: 10.1590/S0100-736X 2011000100010

Fernandes, M. A. M., Gilaverte, S., Buzatti, A., Spren Ger, L. K., Silva, C. J. A., Peres, M. T. P.,... Monteiro, A. L. G. (2015). Método FAMACHA para detectar anemia clínica causada por Haemonchus contortus em cordeiros lactentes e ovelhas em lactação. Pesquisa Veterinária Brasileira, 35(6), 525-530. doi: 10.1590/S0100-736X 2015000600006

Ferreira, J. M., Neto, Viana, E. S., \& Magalhães, L. M. (1981). Patologia clínica veterinária. Belo Horizonte: Rabelo.

Gordon, H. M., \& Whitlock, H. V. (1939). A new technique for counting nematode eggs in sheep faeces. Journal of the Council for Scientific and Industrial Research, 12(1), 50-52.

Hoste, H., \& Torres-Acosta, J. F. J. (2011). Non chemical control of helminths in ruminants: adapting solutions for changing worms in a changing world. Veterinary Parasitology, 180(1-2), 144-154. doi: 10.1016/j.vetpar. 2011.05.035

Instituto Brasileiro de Geografia e Estatística (2018). Produção da pecuária municipal. Rio de Janeiro: IBGE.

Instituto Nacional de Meteorologia (2010). Normais climatológicas do Brasil 19812010. Recuperado de http://www.inmet. gov.br 
Kaplan, R. M., Burke, J. M., Terrill, T. H., Miller, J. E., Getz, W. R., Mobini, S.,... Vatta, A. F. (2004). Validation of the FAMACHA eye color chart for detecting clinical anemia in sheep and goats on farms in the southern United States. Veterinary Parasitology, 123(1-2), 105-120. doi: 10.1016/j.vetpar. 2004.06 .005

Lima, W. C., Athayde, A. C., Medeiros, G. R., Lima, D. A., Borburema, J. B., Santos, E. M.,... Azevedo, S. S. (2010). Nematóides resistentes a alguns anti-helmínticos em rebanhos caprinos no Cariri Paraibano. Pesquisa Veterinária Brasileira, 30(12), 1003-1009. doi: 10.1590/S0100-736X20 10001200001

Maia, D., Rosalinski-Moraes, F., Van Wyk, J. A., Weber, S., \& Sotomaior, C. S. (2014). Assessment of a hands-on method for FAMACHA system training. Veterinary Parasitology, 200(1-2), 165-171. doi: 10. 1016/j.vetpar.2013.11.013

Melo, L. R. B., Vilela, V. L. R., Feitosa, T. F., Almeida, J. L., Neto, \& Morais, D. F. (2013). Anthelmintic resistance in small ruminants from the Semiarid of Paraíba, Brazil. Ars Veterinaria, 29(2), 104-108. doi: 10.15361/2175-0106.2013v29n2p104 $-108$

Molento, M. B. (2004). Resistência de helmintos em ovinos e caprinos. Revista Brasileira de Parasitologia Veterinária, 13(1), 82-87.

Molento, M. B., Fortes, F. S., Pondelek, D. A. S., Borges, F. A., Chagas, A. C. S., TorresAcosta, J. F. J., \& Geldhof, P. (2011). Challenges of nematode control in ruminants: focus on Latin America. Veterinary Parasitology, 180(1-2), 126132. doi: 10.1016/j.vetpar.2011.05.033
Molento, M. B., Gavião, A. A., Depner, R. A., \& Pires, C. C. (2009). Frequency of treatment and production performance using the FAMACHA method compared with preventive control in ewes. Veterinary Parasitology, 162(3-4), 314-319. doi: 10. 1016/j.vetpar.2009.03.031

Molento, M. B., Tasca, C., Gallo, A., Ferreira, M., Bononi, R., \& Stecca, E. (2004). Método FAMACHA@ como parâmetro clínico individual de infecção por Haemonchus contortus em pequenos ruminantes. Ciência Rural, 34(4), 1139-1145.

Nabukenya, I., Akiiki, C. R., Olila, D., Muhangi, D., \& Höglund, J. (2014). Anthelmintic resistance in gastrointestinal nematodes in goats and evaluation of FAMACHA diagnostic marker in Uganda. Veterinary Parasitology, 205(3), 666-675. doi: 10. 1016/j.vetpar.2014.07.019

Nóbrega, J. E., Jr., Riet-Correa, F., Nóbrega, R. S., Medeiros, J. M., Vasconcelos, J. S., Simões, S. V. D., \& Tabosa, I. M. (2005). Mortalidade perinatal de cordeiros no semiárido da Paraíba. Pesquisa Veterinária Brasileira, 25(3), 171-178. doi: 10.1590/ S0100-736X2005000300008

Nogueira, D. M., Eloy, M. A., Sá, C. O., Lopes, E. S., Jr., Salles, H. O., Sá, J. L., \& Sousa, P. H. F. (2011). Manejo reprodutivo. In T. V. Voltolini, Produção de ovinos e caprinos no semiárido (pp. 385-420). Petrolina: EMBRAPA Semiárido.

Poli, C. H. E. C., Monteiro, A. L. G., Barros, C. S. D., Moraes, A. D., Fernandes, M. A. M., \& Piazzetta, H. V. L. (2008). Produção de ovinos de corte em quatro sistemas de produção. Revista Brasileira de Zootecnia, 37(4), 666-673. doi: 10.1590/S151635982008000400012 
Riley, D. G., \& Van Wyk, J. A. (2009). Genetic parameters for FAMACHAC score and related traits for host resistance/resilience and production at differing severities of worm challenge in a Merino flock in South Africa. Veterinary Parasitology, 164(1), 4452. doi: 10.1016/j.vetpar.2009.04.014

Roberts, F. H. S., \& O'Sullivan, P. J. (1950). Methods for egg counts and larval cultures for strongyles infesting the gastro-intestinal tract of cattle. Australian Journal of Agricultural Research, 1(1), 99102. doi: 10.1071/AR9500099

Silva, F. F., Bezerra, H. M. F. F., Feitosa, T. F., \& Vilela, V. L. R. (2018). Nematode resistance to five anthelmintic classes in naturally infected sheep herds in Northeastern Brazil. Revista Brasileira de Parasitologia Veterinária, 27(4), 423-429. doi: 10.1590/ s1984-296120180071

Silva, W. W., Bevilaqua, C. M. L., \& Rodrigues, M. L. A. (2003). Variação sazonal de nematóides gastrintestinais em caprinos traçadores no semi-árido ParaibanoBrasil. Revista Brasileira de Parasitologia Veterinária, 12(2), 71-75.

Torres-Acosta, J. F. J., Sandoval-Castro, C. A., Hoste, H., Aguilar-Caballero, A. J., CámaraSarmiento, R., \& Alonso-Díaz, M. A. (2012). Nutritional manipulation of sheep and goats for the control of gastrointestinal nematodes under hot humid and subhumid tropical conditions. Small Ruminant Research, 103(1), 28-40. doi: 10.1016/j. smallrumres.2011.10.016
VanWyk, J. A., \&Bath, G. F. (2002). The FAMACHA system for managing haemonchosis in sheep and goats by clinically identifying individual animals for treatment. Veterinary Research, 33(5), 509-529. doi: 10.1051/ vetres:2002036

Vieira, L. S., Cavalcante, A. C. R., \& Ximenes, L. J. F. (1997). Epidemiologia e controle das principais parasitoses de caprinos nas regiões semi-áridas do Nordeste. Sobral: EMBRAPA-CNPC.

Vieira, V. D., Vilela, V. L. R., Feitosa, T. F., Athayde, A. C. R., Azevedo, S. S., Souto, D. V. O.,... Melo, L. R. B. (2014). Sheep gastrointestinal helminthiasis in the Sertão region of Paraíba State, Northeastern Brazil: prevalence and risk factors. Revista Brasileira de Parasitologia Veterinária, 23(4), 488-494. doi: 10.1590/s1984-2961 2014089

Vilela, V. L. R., Feitosa, T. F., Braga, F. R., Araújo, J. V., Lucena, S. C., Dantas, E. S.,... Silva, W. W. (2013). Efficacy of Monacrosporium thaumasium in the control of goat gastrointestinal helminthiasis in a semi-arid region of Brazil. Parasitology Research, 112(1), 871-877. doi: 10.1007/ s00436-012-3078-4

Vilela, V. L. R., Feitosa, T. F., Linhares, E. F., Athayde, A. C. R., Molento, M. B., \& Azevedo, S. S. (2012). FAMACHA method as an auxiliary strategy in the control of gastrointestinal helminthiasis of dairy goats under semiarid conditions of Northeastern Brazil. Veterinary Parasitology, 190(1-2), 281-284. doi: 10.10 16/j.vetpar.2012.05.024 
